\title{
Magnesium (Mg) for Citrus Trees ${ }^{1}$
}

\section{Mongi Zekri and Tom Obreza²}

This publication is part of a series about understanding nutrient requirements for citrus trees. For the rest of the series, visit http://edis.ifas.ufl.edu/ topic_series_citrus_tree_nutrients.

To maintain a viable citrus industry, Florida growers must consistently and economically produce large, highquality fruit crops from year to year. Efficiently producing maximum yields of high-quality fruit is difficult without understanding soil and nutrient requirements of bearing citrus trees. Most Florida citrus is grown on soils inherently low in fertility with low cation exchange capacity (CEC) and low water-holding capacity, thus soils are unable to retain sufficient quantities of available plant nutrients against leaching caused by rainfall or excessive irrigation.

Seventeen elements are considered necessary for the growth of green plants: carbon $(\mathrm{C})$, hydrogen $(\mathrm{H})$, oxygen $(\mathrm{O})$, nitrogen $(\mathrm{N})$, phosphorus $(\mathrm{P})$, potassium $(\mathrm{K})$, magnesium $(\mathrm{Mg})$, calcium $(\mathrm{Ca})$, sulfur $(\mathrm{S})$, manganese $(\mathrm{Mn})$, zinc $(\mathrm{Zn})$, iron $(\mathrm{Fe})$, copper $(\mathrm{Cu})$, boron $(\mathrm{B})$, chlorine $(\mathrm{Cl})$, molybdenum (Mo), and nickel (Ni). Plants obtain $\mathrm{C}, \mathrm{H}$, and $\mathrm{O}$ from carbon dioxide and water. The remaining elements, called the "mineral nutrients," are obtained from the soil. Mineral nutrients are classified as macronutrients and micronutrients. The term "macronutrients" refers to those elements that plants require in large amounts $(\mathrm{N}, \mathrm{P}, \mathrm{K}, \mathrm{Mg}, \mathrm{Ca}$, and $S)$. The term "micronutrients" applies to plant nutrients that are essential to plants but are needed only in small amounts ( $\mathrm{Mn}, \mathrm{Zn}, \mathrm{Fe}, \mathrm{Cu}, \mathrm{B}, \mathrm{Cl}, \mathrm{Mo}$, and $\mathrm{Ni}$ ).
Previous articles in this series of EDIS publications discussed the importance of avoiding deficiency of N, P, and $\mathrm{K}$ when managing nutrients in citrus trees. This publication discusses magnesium $(\mathrm{Mg})$ requirements for citrus trees.

\section{Functions and Importance of $\mathbf{M g}$}

Magnesium is an essential constituent of chlorophyll; it is the center of the chlorophyll molecule. Magnesium is involved in photosynthesis, and it plays an important role as an activator of several enzymes. It is also involved in carbohydrate metabolism and synthesis of nucleic acids. Magnesium influences the movement of carbohydrates from leaves to other parts of the tree, and it also stimulates $P$ uptake and transport. Seedy citrus varieties may need more $\mathrm{Mg}$ than seedless ones because seeds store a large amount of Mg. Dolomitic limestone is often used to correct acidity; this liming material supplies slowly available $\mathrm{Mg}$ as well as Ca. Calcium is abundant in alkaline soils, which can be antagonistic to $\mathrm{Mg}$ uptake.

1. This document is SL380, one of a series of the Department of Soil and Water Science, UF/IFAS Extension. A version of this article was previously published in Citrus Industry magazine. Original publication date: July 2013. Visit the EDIS website at http://edis.ifas.ufl.edu.

2. Mongi Zekri, multicounty citrus UF/IFAS Extension agent; and Tom Obreza, professor and interim associate dean for Extension; UF/IFAS Extension, Gainesville, FL 32611. 
Table 1. Guidelines for interpretation of orange tree leaf $\mathrm{Mg}(\%)$ analysis based on 4- to 6-month-old spring flush leaves from nonfruiting twigs

\begin{tabular}{|l|c|c|c|c|c|}
\hline & Deficient & Low & Optimum & High & Excessive \\
\hline $\mathrm{Mg}$ & $<0.20$ & $0.20-0.29$ & $0.30-0.49$ & $0.50-0.70$ & $>0.70$ \\
\hline
\end{tabular}

Table 2. Interpretation of soil analysis data for Mg (ppm)* using the Mehlich 1 (double-acid) extractant

\begin{tabular}{|l|r|r|r|}
\hline & Low & Medium & High \\
\hline Mg & $<15$ & $15-30$ & $>30$ \\
\hline *parts per million $(\mathrm{ppm}) \times 2=$ lbs/acre & & \\
\hline
\end{tabular}

Table 3. Adjusting fertilization based on soil analysis

\begin{tabular}{|l|l|l|}
\hline \multicolumn{1}{|l|}{} & When below sufficiency & When above sufficiency \\
\hline Soil $\mathrm{pH}$ & Lime to $\mathrm{pH} 6.0$ & $\begin{array}{l}\text { 1. Do nothing. } \\
\text { 2. Use acid-forming } \mathrm{N} \text { fertilizer. } \\
\text { 3. Apply elemental sulfur. } \\
\text { 4. Use rootstocks tolerant to high } \mathrm{pH} .\end{array}$ \\
\hline $\mathrm{Mg}$ & $\begin{array}{l}\text { 1. Check soil } \mathrm{pH} \text { and adjust with dolomitic lime if needed. } \\
\text { 2. Check leaf } \mathrm{Mg} \text { status. }\end{array}$ & $\begin{array}{l}\text { 1. Do nothing. } \\
\text { 2. Check leaf } \mathrm{K} \text { status. }\end{array}$ \\
\hline
\end{tabular}

Table 4. Effects of Mg on citrus fruit quality

\begin{tabular}{|c|c|}
\hline Variable & Rating \\
\hline \multicolumn{2}{|c|}{ Juice Quality } \\
\hline Juice Content & 0 \\
\hline Soluble Solids (SS) & + \\
\hline Acid $(A)$ & 0 \\
\hline SS/A Ratio & + \\
\hline Juice Color & $?$ \\
\hline Solids/Box & + \\
\hline Solids/Acre & + \\
\hline \multicolumn{2}{|c|}{ External Fruit Quality } \\
\hline Size & + \\
\hline Weight & + \\
\hline Green Fruit & 0 \\
\hline Peel Thickness & - \\
\hline
\end{tabular}

If soil $\mathrm{Mg}$ level is low, apply $\mathrm{Mg}$ fertilizer at a rate equal to $20 \%$ of the $\mathrm{N}$ rate. Magnesium nitrate may also be applied as a foliar spray. Curtail $\mathrm{Mg}$ fertilizer application if a subsequent soil test shows $\mathrm{Mg}$ is in the high range.

\section{Mg Behavior in Florida Soils}

- Mg exists as solid compounds in the soil (mostly in combination with carbonate or phosphate) and in ionic forms held by the cation exchange complex.
- Solid forms of Mg are sparingly soluble; they can reside in the soil for many years if the $\mathrm{pH}$ is not too acidic. Dissolution is more rapid at low $\mathrm{pH}$, which is the basis of the liming reaction.

- Mg slightly increases total soluble solids per box and per acre, and soluble solid-acid ratio.

- Mg slightly increases fruit size and weight, but decreases rind thickness. 


\section{Magnesium Deficiency}

Magnesium deficiency has been a major problem in citrus production. In Florida, Mg deficiency is commonly referred to as "bronzing." Trees with inadequate Mg may have no symptoms in the spring growth flush, but leaf symptoms develop as the leaves age and the fruit expand and mature in the summer and fall. Magnesium deficiency symptoms occur on mature leaves following the removal of $\mathrm{Mg}$ to satisfy fruit requirements.

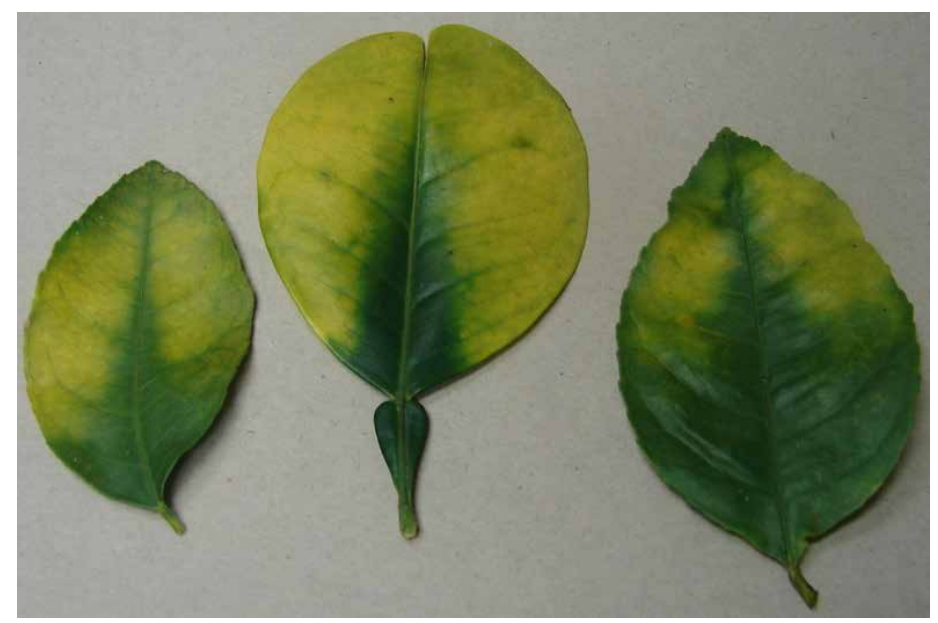

Figure 1. These leaves show magnesium-deficiency symptoms, including disconnected yellow areas and midribs with an inverted V-shaped green area.

Credits: M. Zekri

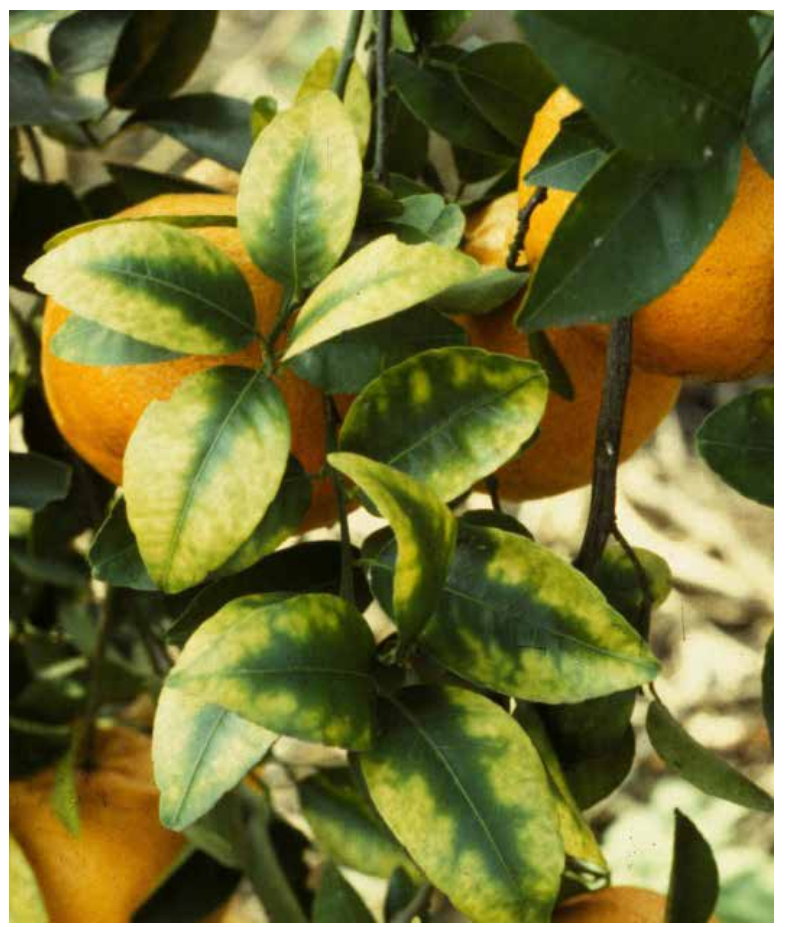

Figure 2. The leaves on this citrus tree show magnesium-deficiency symptoms. Notice how the leaves have an inverted V-shaped area pointed on the midrib.

Credits: M. Zekri
During the summer, when a rapid increase in fruit size occurs, the symptoms appear on leaves close to the developing fruit. Magnesium deficiency symptoms appear as a result of translocation of $\mathrm{Mg}$ from the leaves to the developing fruit, although there may also be a translocation from older leaves to young developing leaves on the same shoot. Disconnected yellow areas or irregular yellow blotches start near the base along the midribs of mature leaves close to fruit. These blotches become gradually larger and eventually coalesce to form a large area of yellow tissue on each side of the midrib. This yellow area enlarges until only the leaf tip and base are green, showing an inverted V-shaped area pointed on the midrib. In acute deficiency, the yellow area may gradually enlarge until the entire leaf becomes yellow or bronze in color.

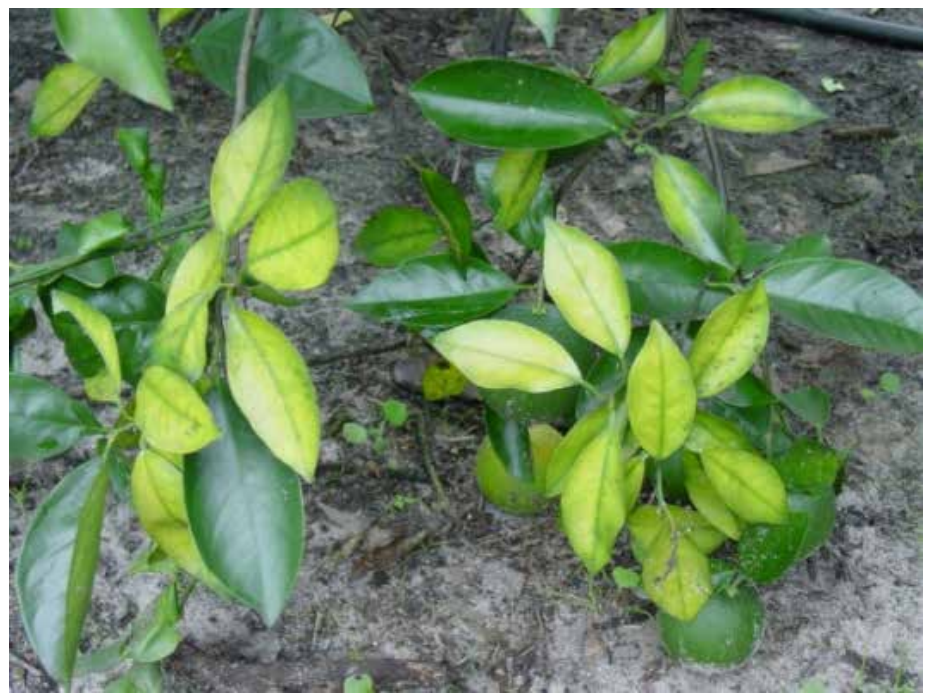

Figure 3. These leaves show severe Mg-deficiency symptoms, including entire leaves yellowing and bronzing.

Credits: M. Zekri

Leaves that lose most of their green color drop freely during unfavorable conditions, including cold weather, water stress, or concentrated foliar sprays. Defoliated twigs are weak and usually die by the following spring, necessitating pruning of trees. There are neither primary twig symptoms nor striking fruit symptoms associated with $\mathrm{Mg}$ deficiency, but a secondary effect following defoliation may lead to the death of many twigs. Severe defoliation reduces the average size of individual fruit and causes a general decline in fruit production.

The mobility of $\mathrm{Mg}$ in the tree differentiates it from Fe, $\mathrm{Zn}$, $\mathrm{Mn}$, and $\mathrm{Cu}$. Deficiency symptoms of these micronutrients develop on new growth, while $\mathrm{Mg}$ deficiency occurs only on mature leaves that were previously normal in appearance, usually on limbs bearing a heavy crop. Heavily fruited limbs develop extreme $\mathrm{Mg}$ deficiency symptoms and may 
even become completely defoliated, while limbs with little or no fruit may not show deficiency symptoms.

Cultivars producing seedy fruit are more severely affected by $\mathrm{Mg}$ shortage than cultivars producing seedless fruit.

Alternate bearing is common in seedy cultivars growing in an Mg-deficient condition. The loss of wood as a result of defoliation reduces the fruit-bearing wood for the following year. Magnesium deficiency can greatly reduce both fruit yield and fruit quality. Fruits from Mg-deficient trees are lower in soluble solids, acidity, and vitamin C. Magnesiumdeficient trees are more susceptible to cold injury than non-deficient trees.

Mg deficiency in Florida is caused primarily by low soil $\mathrm{Mg}$ concentration. It is particularly severe on acidic sandy soils where $\mathrm{Mg}$ readily leaches. Leaching of added $\mathrm{Mg}$ is particularly serious and substantially rapid when soil $\mathrm{pH}$ is $4.5-5.0$. Under such conditions, using dolomite to raise the $\mathrm{pH}$ to 6.0-6.5 furnishes $\mathrm{Mg}$ at the same time. Soil application of $\mathrm{Mg}$ sulfate or oxide can successfully correct Mg deficiency when soil $\mathrm{pH}$ is raised. Soil salinity, fertilizers high in potassium salts, and manures have induced or aggravated Mg deficiency. Magnesium deficiency can also be attributed to calcareous soils relatively low in $\mathrm{Mg}$ or to unbalanced conditions in the soil caused by excessive $\mathrm{K}$ or $\mathrm{Ca}$. Under these conditions, the amount of $\mathrm{Mg}$ applied must be greater than that applied to soils lower in Ca or K.

In Florida, one foliar spray application of $\mathrm{Mg}$ is not always effective to correct $\mathrm{Mg}$ deficiency because the amount of $\mathrm{Mg}$ needed is often greater than the amount the leaves can absorb. Foliar sprays of $\mathrm{Mg}$ nitrate can be effective when applied to the spring and summer flush leaves that are twothirds to fully expanded but not hardened off. Leaves that already developed a deficiency pattern will not completely recover when $\mathrm{Mg}$ is applied, but deficiency symptoms can be prevented the following season.

The following are common solid Mg sources for soil application:

- Magnesium carbonate (dolomitic lime)

- Potassium-magnesium sulfate (sul-po-mag)

- Magnesium sulfate

- Magnesium oxide

Mg nutrient sources used to manufacture fertilizer solutions or applied in foliar sprays include the following:

- Magnesium nitrate

\section{Conclusion}

Supplying sufficient nutrition should be a high-priority management practice for every grower. An appropriate nutrient balance using fertilizer management is necessary to achieve sufficient plant nutrition for best fruit yield and quality. If an element is below the critical level, yield production will fall even though the other elements are kept in good supply. Balanced use of plant nutrients corrects nutrient deficiencies and toxicities, improves soil fertility, increases nutrient- and water-use efficiency, enhances crop yields and fruit quality, develops tree tolerance to pests, diseases, and other stresses, and improves environmental quality. 